ORIGINAL ARTICLE

\title{
Correlation between serum bilirubin and serum ferritin Level in thalassaemia patients
}

\author{
N Sultana1, S Sadiya ${ }^{2}$, MH Rahman 1 \\ 1Dept. of Biochemistry, Dhaka Medical College, Dhaka \\ 2Dept. of Biochemistry, Dhaka Shishu Hospital, Dhak
}

\begin{abstract}
Thalassaemia is the most common hereditary disorder in the world including Bangladesh. Beta thalassaemia major and $\mathrm{Hb}$-E thalassaemia both are common in our country. Iron overload causes most of the mortality and morbidity associate with thalassaemia. To assess the iron over load and liver function a cross sectional comparative study was carried out in the Department of Biochemistry, Dhaka Medical College, Dhaka in collaboration with Thalassaemia Center and Department of Pathology, Dhaka Shishu Hospital, Dhaka during the period of July 2006 to June 2007. The study was carried out with the patients who visited regularly in Dhaka Shishu Hospital Thalassaemia Centre (DSHTC) and had multiple transfusions (more than five) and age more than 2 years. To compare the state of liver function with normal healthy individuals' normal healthy persons were also included. Total 70 subjects were included in this study. The study subjects were distributed into two groups, the group - A (cases, $n=40$ ) and group - $B$ (healthy controls, $n=30$ ). According to the major types of thalassaemia present in our country, group -A again divided into two, group AI $\beta$-thalassaemia major $(n=12)$ and group - AII of Hemoglobin E $\beta$-thalassaemia $(n=28)$. The mean of serum Bilirubin in group - A and group - B were $(2.04 \pm 0.70) \mathrm{mg} / \mathrm{dl}$ and $(0.67 \pm 0.15) \mathrm{mg} / \mathrm{dl}$ respectively. Group - A had higher serum bilirubin than group -B in $\mathrm{p}$ value $<0.001$. The mean level of serum bilirubin in group - AI was $(1.70 \pm 0.70) \mathrm{mg} / \mathrm{dl}$ and the mean of bilirubin in group AII was $(2.18 \pm 0.66) \mathrm{mg} / \mathrm{dl}$. Group -AI had lower serum bilirubin than group AII in $\mathrm{p}$ value $<0.05$. Pearson's correlation between serum bilirubin and serum ferritin had $\mathrm{r}$ value -0.26 was statistically not significant. Mean level of serum ferritin in the total was $(2729.40 \pm 1935.87) \mathrm{ng} / \mathrm{ml}$, minimum level was $304 \mathrm{ng} / \mathrm{ml}$ and maximum was $7256 \mathrm{ng} / \mathrm{ml}$. Mean level of serum ferritin in the patients of $\beta$ - thalassaemia major was $(4098.67 \pm 1598.63) \mathrm{ng} / \mathrm{ml}$, minimum level was $1212 \mathrm{ng} / \mathrm{ml}$ and maximum was $7560 \mathrm{ng} / \mathrm{ml}$. Mean level of serum ferritin in the patients of $\mathrm{HbE} \beta$ - thalassaemia was $(2232.57 \pm 1598.63) \mathrm{ng} / \mathrm{ml}$, minimum level was $304 \mathrm{ng} / \mathrm{ml}$ and maximum was $630 \mathrm{ng} / \mathrm{ml}$. Group AI had higher level of serum ferritin than group AII in p value $<0.05$.

In conclusion, iron over load and jaundice are common finding of thalassaemia. In this present study serum ferritin and serum bilirubin parameter of iron over load and jaundice are correlated. But no statistical correlation was found between these two parameters.
\end{abstract}

Key words: thalassaemia, serum bilirubin, serum ferritin.

\section{Introduction}

Thalassaemia is the most common hereditary disorder in the world including Bangladesh. Thalassaemia is a major health problem all over the world but this is particularly in the developing countries where the resources are limited $^{1}$. Thalassaemia is characterized by production of reduce normal hemoglobin due to absent or decrease synthesis of one or more type of polypeptide chain ${ }^{2}$. Hemoglobinopathies are characterized by the production of structurally defective hemoglobin due to abnormalities in the formation of globin moiety of the molecule ${ }^{2}$. There are two main classes of thalassaemia called alpha- and beta thalassaemia that result from defective alpha- and beta chain synthesis respectively. There is rare form in which both beta and delta chain production are reduced, delta-beta thalassaemia, or in which epsilon, 
gamma, delta and beta chain production are defective, epsilon-gamma- delta-beta thalassaemia ${ }^{3}$. Alpha- thalassaemia is characterized by reduced or suppressed production of alpha-globin chain ${ }^{4}$. It is found most commonly in individuals with an ethnic background of Southeast Asia, Southern China, the Middle East, India, Africa and the Mediterranean. Clinically there are four alphathalassaemia syndromes. These occur because of inheritance of molecular mutations affecting the output of one, two, three or four of the -globin genes $^{5}$. Beta thalassaemia is caused by decreased or suppress production of beta-globin chain. It is the most important type of thalassaemia, because it is common and usually produce severe anemia in homozygous and heterozygous status ${ }^{2}$. Clinically beta-thalassaemias are heterogeneous group of disorders and three types, betathalasaemia minor or beta-thalassaemia trait, beta-thalassaemia intermedia and betathalassaemia major. Beta thalassaemias occur widely in a broad belt, ranging from the Mediterranean and parts of north and West Africa through the Middle East and Indian subcontinent to South East Asia ${ }^{6}$. Hb-E betathalassaemia is the commonest severe form of thalassaemia in South East Asia and part of Indian subcontinent. It is the most common form of thalassaemia in Bangladesh. $\mathrm{Hb}-\mathrm{E}$ is ineffectively synthesized and hence, when it inherited together with beta-thalassaemia there is marked deficiency of beta-chain production. The clinical and hematological changes are variable ${ }^{6}$. Clinically it is again divided into mild, moderate and severe form. Severe form of this type of thalassaemia shows clinical manifestations as beta-thalassaemia major. With the better treatment, survival of the patients with these disorders increase represents one of the most dramatic alteration in morbidity and mortality associated with a genetic disease in 19th century and the subjects are being constantly reviewed ${ }^{7}$.

Beta thalassaemia major and Hb-E thalassaemia both are common in our country. A conservative world health report has estimated that three percent are carrier of beta-thalassaemia and four percent are carriers of $\mathrm{Hb}-\mathrm{E}$ beta-thalassaemia8. A recent study on school children in different district of Bangladesh has shown overall prevalence of beta-thalassaemia trait was $4.1 \%$ and $\mathrm{Hb}-\mathrm{E}$ beta-thalassaemia was $6.1 \%$. Calculated value of the expected births of betathalassaemia major annually in our country is 1040 and $\mathrm{Hb}-\mathrm{E}$ beta-thalassaemia is 64439. Due to availability of improved health service and diet the death of children from diarrhea, respiratory tract infection and malnutrition has been fallen, more children are now surviving and visiting hospital with hereditary disorders like thalassaemia. Proper management of thalassaemia patient can decrease morbidity and mortality and they can survive with a good quality of life up to third or fourth decade. Children who suffer from this disease need a lifelong repeated blood transfusion to maintain their hemoglobin level around $12 \mathrm{~g} / \mathrm{dl}$, but unfortunately those will cause an accumulation of iron in various tissue accompanied by an increase serum iron level ${ }^{9}$. Iron over load occurs when iron intake is increased over a sustained period of time, either from the transfusion of red cells or because there is increased absorption of iron from digestive tract. Both of these occur in thalassaemia, blood transfusion being the major cause in thalassaemia major and increased iron absorption being more important cause in thalassaemia intermedia. Because there is no mechanism in human to excrete the excess iron, this has to be removed by chelating agent ${ }^{10}$. Iron overload causes most of the mortality and morbidity associate with thalassaemia. Iron deposition occurs in visceral organs mainly in heart, liver and endocrine glands causing tissue damage and ultimately gastrointestinal absorption are contributory. Paradoxically, excess gastrointestinal iron absorption persists despite massive increases in total body iron load. Hepcidin is a small peptide that inhibits iron absorption in the small bowel. Hepcidin levels normally increase when iron stores are elevated. Its levels were found to be inappropriately low in patients with thalassaemia intermedia and thalassaemia major ${ }^{11}$. 
The combination of iron overload and increase outpouring of catabolic iron from the reticuloendothelial system overwhelm the iron binding capacity of transferrin, resulting in the emergence of toxic non transferrin bound plasma iron (NTBI). NTBI promotes the formation of free hydroxyl radicals and accelerates the peroxidation of membrane lipids. Both lipid peroxidation and TGFbeta-1 expression resulted from iron over load may promote hepatic injury and fibrogenesis 12 . Furthermore beta-thalassaemia and $\mathrm{Hb}-\mathrm{E}$ betathalassaemia patients treated with blood transfusion are also liable to infected with Hepatitis B and Hepatitis C if proper screening is not done which can cause hepatic fibrosis and cirrhosis 13 . So thalassaemia patients must be routinely checked for liver function.

In the condition of iron accumulation and chronic viral hepatitis, there is an increase of serum iron level, transferrin saturation and ferritin level. Ferritin is an intracellular storage iron, which is present mainly in the reticuloendothelial cells. Clinically significant concentration is found in serum and the level of serum ferritin reflects total body iron stores 14,15 . A serum ferritin concentration reflects iron storages in health and also in certain diseases 16 . Ferritin a high molecular weight iron containing protein, acts in human body as an iron storage depot. It is a major iron storage protein of liver, spleen, bone marrow and other tissue of the body. Its two major functions are to remove excess iron from cells converting it into a harmless soluble form, and to provide a mobilizable reserve of iron which can be drawn when needed. Most of the ferritin is intracellular but the measurement of circulating serum ferritin reflects the level of the body iron store 17,18 .

To judge the extension of liver cell damage caused by iron accumulation, a very sensitive indicator for liver function, serum bilirubin was assessed. Hyperbilirubinaemia may be found in prehepatic (haemolytic), hepatic, and post hepatic (obstructive).
Thalassaemia patients if treated with proper blood transfusion and chelating therapy they can maintain apparently normal life but for the maintenance of healthy life they should be routinely checked for their liver function, cardiac function and endocrine function.

\section{Materials and Methods}

A cross sectional comparative study carried out in the department of Biochemistry, Dhaka Medical College, Dhaka in collaboration with Thalassaemia Center and department of Pathology, Dhaka Shishu Hospital, Dhaka during the period of July 2006 to June 2007. The study was carried out with the patients who visited regularly in Dhaka Shishu Hospital Thalassaemia Centre (DSHTC) and have multiple transfusions (more than five) and the age more than 2 years. To compare the state of liver function with normal healthy individuals' normal healthy persons were also included. Total 70 subjects were included in this study. The study subjects were distributed into two groups, the group - A (cases) and group - B (healthy controls). Group - A consisted of 40 thalassaemia patients and group - B consisted of 30 healthy individuals. According to the major types of thalassaemia present in our country, group -A again divided into two, group - AI patients of beta-thalassaemia major included 12 patients and group - AII patients of Hemoglobin E beta-thalassaemia included 28 patients. Inclusion and exclusion criteria were considered. The inclusion criteria were a. Diagnosed case of thalassaemia major and hemoglobin $\mathrm{E}$ betathalassaemia who have transfused more than five times, b. Age: two years and above, c. Sex: both sexes. Exclusion criteria were a. Below two years, b. Other hemolytic disorders, c. Acute systemic illness and d. Hepatitis B or Hepatitis C positive patients. The patients who fulfill the inclusion and exclusion criteria were selected for the study. After taking informed written consent of all the subjects, necessary information were recorded in a pre-designed pre-tested structured questionnaire. The questionnaire included name, age, sex, blood 
group, economic status, $\mathrm{Hb}$ electrophoresis report, age of diagnosis, number of transfusion taken, state and type of chelating therapy, Hepatitis B and Hepatitis C status, Hepatitis B vaccination status and dietary habit of patients. After that $5 \mathrm{ml}$ of venous blood sample was drawn in a sterile test tube aseptically by venipuncture with sterile disposable syringe. Blood sample was taken in a plain sterile test tube, and kept for half an hour for clotting and then centrifuged. Supernatant clear serum was taken in two separate test tubes for the estimation of serum ferritin and serum bilirubin of the patients. For serum bilirubin estimation special precaution was taken to prevent oxidation. Data were entered in IBM PC and SPSS software (version 11.5) used to analyze data. Data were expressed as mean \pm SD. Value of the serum bilirubin compares to see the case and control by using independent sample "t" test. Difference between serum bilirubin and ferritin in two groups of thalassaemia is also compared by using the Student's " $t$ " test. P value less than 0.05 was taken as level of significance. Serum bilirubin was correlated with serum ferritin and correlation was done by using Pearson's correlation test using the same SSPS programme.

\section{Results}

Total forty subjects of thalassaemia of which, patients of beta-thalassaemia major (group AI) were 12 and patients of hemoglobin E betathalassaemia (group AII) were 28. The observation and finding about the patients age, sex, blood group, economic status, $\mathrm{Hb}$ electrophoresis report, age of diagnosis, number of transfusion taken, state and type of chelating therapy, Hepatitis B and Hepatitis C status, Hepatitis B vaccination status and dietary habit has been observed. Prothrombin time and serum ferritin were expressed as mean \pm SD. Healthy individual $(n=30)$ were considered as the same age group. Their serum bilirubin was also expressed as mean $\pm \mathrm{SD}$.

Age - mean age of the 40 patients was 8.32 \pm 5.17 years, minimum age was 2 years and maximum age was 20 years. Mean age of the 30 normal healthy individuals was $7.97 \pm 4.62$ years, minimum and maximum age was same as cases. Mean difference among case and control was 0.36 , p value was 0.76 (table - I). Sex among the 40 patients $26(65 \%)$ were male and 14(35\%) were female. Among the 30 control 19 $(66.3 \%)$ were male and $11(37.3 \%)$ were female. Blood group -among 40 patients $10(25 \%)$ had A positive, 14 had $\mathrm{B}$ positive, $12(30 \%)$ had $\mathrm{O}$ positive and $4(10 \%)$ had $\mathrm{AB}$ positive blood group. Hemoglobin electrophoresis report among 40 patients $12(30 \%)$ had betathalassaemia major and $28 \quad(70 \%)$ had hemoglobin E beta-thalassaemia. Chelating therapy - among the 40 patients $26(65 \%)$ had taken chelating therapy and 14(35\%) had not taken chelating therapy. Hepatitis B and Hepatitis C status - all of the 40 patients $(100 \%)$ were Hepatitis $\mathrm{B}$ and Hepatitis $\mathrm{C}$ negative. Hepatitis B vaccination status - among the 40 patients $36(90 \%)$ were completely vaccinated 4 (10\%) were not vaccinated. Dietary habit among the 40 patients $39(97.5 \%)$ had followed the diet chart which was advised by the physicians for consumption of low iron content only 1 patient $(2.5 \%)$ had not followed the dietary advice. Table - II shows different general characters distribution of the thalassaemia patients.

Serum Bilirubin : The mean of serum Bilirubin in group - A (case) and group - B (control) were $(2.04 \pm 0.70) \mathrm{mg} / \mathrm{dl}$ and $(0.67 \pm 0.15) \mathrm{mg} / \mathrm{dl}$ respectively. A statistically significant mean difference of bilirubin was found indicating group - A had higher bilirubin than group -B in $\mathrm{p}$ value $<0.001$ (table - III) the mean level of serum bilirubin in group - AI (beta thalassaemia major) was $(1.70 \pm 0.70) \mathrm{mg} / \mathrm{dl}$ and the mean of bilirubin in group AII ( $\mathrm{HbE}$ beta thalassaemia) was $(2.18 \pm 0.66) \mathrm{mg} / \mathrm{dl}$. A statistically significant mean difference of bilirubin was found indicating group -AI had lower bilirubin than group AII in $\mathrm{p}$ value $<0.05$ (table - IV). Peaeson's Correlation between serum bilirubin of patients in $\mathrm{mg} / \mathrm{dl}$ and serum ferritin of patients in $\mathrm{ng} / \mathrm{ml}$ had studied in two 
Correlation Between Serum Bilirubin and Serum Ferritin Level

ways as a whole correlation between bilirubin of all the patients in $\mathrm{mg} / \mathrm{dl}$ and serum ferritin in $\mathrm{ng} / \mathrm{ml}$ had $\mathrm{r}$ value -.26 was statistically insignificant at $0 / 05$ level (table - V). on the other side correlation between serum bilirubin of the patient of beta - thalassaemia major in $\mathrm{mg} / \mathrm{dl}$ and serum ferritin of same patients in $\mathrm{ng} / \mathrm{ml}$ had $\mathrm{r}$ value -0.10 was statistically insignificant at the 0.05 level. And correlation between serum bilirubin of the patients of $\mathrm{HbE}$ beta - thalassaemia in $\mathrm{mg} / \mathrm{dl}$ and serum ferritin of same patients in $\mathrm{ng} / \mathrm{ml}$ had $\mathrm{r}$ value -0.16 was statistically insignificant at the level 0.05 (table - VI).

Serum Ferritin: Out of the 40 patients 10 patients $(25 \%)$ had below $1001 \mathrm{ng} / \mathrm{ml}$ serum ferritin, 6 patients (15\%) had 1001 - 2000 $\mathrm{ng} / \mathrm{ml}, 8$ patients $(20 \%)$ had $2001-3000 \mathrm{ng} / \mathrm{ml}$, 6 patients $(15 \%)$ had $3001-4000 \mathrm{ng} / \mathrm{ml}$, and 10 patients (25\%) had more than $4001 \mathrm{ng} / \mathrm{ml}$ serum ferritin (table - VII). Mean level of serum ferritin in the total was $(2729.40 \pm 1935.87)$ $\mathrm{ng} / \mathrm{ml}$, minimum level was $304 \mathrm{ng} / \mathrm{ml}$ and maximum was $7256 \mathrm{ng} / \mathrm{ml}$. Mean level of serum ferritin in the patients of beta - thalassaemia major was (4098.67 \pm 1598.63$) \mathrm{ng} / \mathrm{ml}$, minimum level was $1212 \mathrm{ng} / \mathrm{ml}$ and maximum was $7560 \mathrm{ng} / \mathrm{ml}$. Mean level of serum ferritin in the patients of $\mathrm{HbE}$ beta - thalassaemia was $(2232.57 \pm 1598.63) \mathrm{ng} / \mathrm{ml}$, minimum level was $304 \mathrm{ng} / \mathrm{ml}$ and maximum was $630 \mathrm{ng} / \mathrm{ml}$. A statistically significant mean difference of ferritin was found indicating ferritin of group AI (patients of beta - thalassaemia major) had higher level of ferritin than group AII (patients of HbEbeta - thalassaemia ) in $\mathrm{p}$ value $<0.05$ (table - VIII).

Table-I: Mean age distribution of thalassaemia patients (case) and normal healthy individuals (control)

\begin{tabular}{lllccl}
\hline Variable & Group & $\mathrm{N}$ & Mean \pm SD & Mean difference & $\mathrm{P}$ \\
\hline Age & Case & 40 & $8.32 \pm 5.17$ & 0.30 & $\mathrm{NS}$ \\
& Control & 30 & $7.97 \pm 4.62$ & & 0.76 \\
\hline
\end{tabular}

$P$ value reached from independent sample student's " $\mathrm{t}$ " test. NS $=$ not significant $(\mathrm{p}>0.05)$
Table-II: Different general characters distribution of thalassaemia patients

\begin{tabular}{llll}
\hline Variables & & $\mathrm{N}$ & $\%$ \\
\hline \multirow{2}{*}{ Sex } & Male & 26 & 65 \\
& Female & 14 & 35 \\
Blood group & A+ve & 10 & 25 \\
& B+ve & 14 & 35 \\
& O+ve & 12 & 30 \\
Type of thalassaemias & AB+ve & 04 & 10 \\
& H-thalassaemia major & 12 & 30 \\
State of chelation & Taken thalassaemia & 28 & 70 \\
Hepatitis B vaccination & Not taken & 26 & 65 \\
Dietary advice & Vaccinated & 14 & 35 \\
& Followed & 36 & 90 \\
\hline
\end{tabular}

Table-III: Level of serum Bilirubin in $\mathrm{mg} / \mathrm{dl}$ in case and in control

\begin{tabular}{llllll}
\hline Parameter & Group & $\mathrm{N}$ & Mean $\pm \mathrm{SD}_{\text {difference }}^{\text {Mean }}$ & $\mathrm{p}$ \\
\hline $\begin{array}{l}\text { Serum Bilirubin } \\
(\mathrm{mg} / \mathrm{dl})\end{array}$ & Case & 40 & $2.04 \pm 0.70$ & 1.36 & $10.46<0.001$ \\
\hline
\end{tabular}

$P$ value reached from independent sample Student's " $t$ " test. $S=$ significant $(p<0.001)$

Table-IV: Level of serum Bilirubin in $\mathrm{mg} / \mathrm{dl}$ in two types of thalassaemia patients

\begin{tabular}{lllccc}
\hline Parameter & Type of thalassaemia N & Mean \pm SD & $\begin{array}{c}\text { Mean } \\
\text { difference }\end{array}$ & $\mathrm{t}$ & $\mathrm{P}$ \\
\hline $\begin{array}{l}\text { S Bilirubin } \\
(\mathrm{mg} / \mathrm{dl})\end{array}$ & $\beta$-thalassaemia major 12 & $1.7 \pm 0.70$ & 0.48 & 2.08 & 0.04 \\
Hb-E $\beta$-thalassaemia & 28 & $2.18 \pm 0.66$ & & & \\
\hline
\end{tabular}

$P$ value reached from Independent sample student's " $t$ " test. $S=$ significant $(p<0.05)$

Table-V: Pearson's Correlation between serum Bilirubin of patient in $\mathrm{mg} / \mathrm{dl} \&$ serum Ferritin of patient in $\mathrm{ng} / \mathrm{ml}$

\begin{tabular}{lll}
\hline Correlation between & $\mathrm{r}$ & Interpretation \\
\hline Serum Bilirubin in $\mathrm{mg} / \mathrm{dl} \&$ & -.261 & Weak negative correlation \\
Serum Ferritin of patient in $\mathrm{ng} / \mathrm{ml}$ & & \\
\hline
\end{tabular}

$r$ value -.26 was statistically insignificant at the 0.05 level

Table-VI: Showing Pearson's Correlation between serum Bilirubin in $\mathrm{mg} / \mathrm{dl} \&$ serum Ferritin of patient in $\mathrm{ng} / \mathrm{ml}$ in $\beta$ - thalassaemia major and $\mathrm{Hb}$ E $\beta$ thalassaemia

\begin{tabular}{lll}
\hline Type of thalassaemia & r value & Interpretation \\
\hline$\beta$ - thalassaemia & -0.10 & No correlation \\
Hb E $\quad \beta$-thalassaemia & -0.16 & No correlation \\
\hline
\end{tabular}

No correlation at the 0.05 level 
Table-VII: Distribution of serum Ferritin in thalassaemia patients

\begin{tabular}{cclc}
\hline & Frequency & Percentage & Ferritin level in $\mathrm{ng} / \mathrm{ml}$ \\
\hline 10 & 25 & $<1000$ \\
6 & 15 & $1000-2000$ \\
8 & 20 & $2001-3000$ \\
& 6 & 15 & $3001-4000$ \\
& 10 & 25 & $>4000$ \\
Total & $=40$ & 100 & \\
\hline
\end{tabular}

Table-VIII: Difference in serum Ferritin level between two types of thalassaemia

\begin{tabular}{lcccccc}
\hline $\begin{array}{l}\text { S Ferritin } \\
\text { level } \mathrm{ng} / \mathrm{ml}\end{array}$ & Type of thalassaemia & $\mathrm{N}$ & Mean $\pm \mathrm{SD}$ & $\begin{array}{c}\text { Mean } \\
\text { difference }\end{array}$ & $\mathrm{t}$ & $\mathrm{P}$ \\
\hline $\begin{array}{l}\text { B-thalassaemia major } \\
\mathrm{Hb}-\mathrm{E} \quad \beta \text {-thalassaemia } \\
\text { major }\end{array}$ & 28 & $2232.57 \pm 1598.62$ & & & \\
\hline
\end{tabular}

$P$ value reached from Independent sample Student's " $t$ " test. Significant $(p<0.05)$

\section{Discussion}

Beta thalassaemia major and $\mathrm{Hb}-\mathrm{E}$ Beta thalassaemia is common in our country. The thalassaemia patient develops liver fibrosis as a result of iron overload due to excessive blood transfusion and also from excess intestinal absorption. In recognizing the hepatotoxic potentials of iron over load the cross sectional comparative study had been under taken to find the state of liver function in the thalassaemia patients. In addition serum ferritin level also had been determined in the patients to find the relation of serum ferritin with liver function test.

In this study $30 \%$ patients had beta thalassaemia major and $70 \%$ patients had $\mathrm{Hb}$ Ebeta - thalassaemia, this finding showed second group of patients were more than double of first one. This finding was not in accordance with Purnamawati SP et al and Daniel et al19. They had studied on more number of beta thalassaemia major patients. Chelation therapy was taken $65 \%$ and $35 \%$ was not taken chelation therapy. This finding revealed that about two third of the patients were alert about their iron overload and were taking the proper management, this finding also is not consisted with Purnawati SP et al19. They were studied
N Sultana, S Sadiya et al

on irregularly chelated patients. Hepatitis B and Hepatitis C patients were $100 \%$ negative, actually during collection of sample from the patients 1 Hepatitis $\mathrm{C}$ positive patient was found he had excluded from the study in order to avoid possibility of undue influence on liver function. Regarding Hepatitis B vaccination 90\% were completely vaccinated $10 \%$ were not vaccinated. This finding pointed that most of the patients were conscious that they might be infected through blood transfusion and had taken necessary action. The diet chart which was advised by the physicians for consumption of low iron content had followed $97.5 \%$ and had not followed only $2.5 \%$. This finding again revealed that the patients and their parents were very much concern about their disease and as per direction of the physicians they have taken proper steps.

The mean level of serum bilirubin in patient of thalassaemia, and normal healthy children were $(2.04 \pm 0.70) \mathrm{mg} / \mathrm{dl}$ and $(0.67 \pm 0.15) \mathrm{mg} / \mathrm{dl}$ respectively. The total mean bilirubin was $(1.46 \pm 0.86)$. a statistically signifi98cant mean difference of serum bilirubin was found indicating patient of thalassaemia had higher bilirubin than normal healthy children in $\mathrm{p}$ value $<0.001$ level. Serum bilirubin may increase in thalassaemia due to haemolysis of red blood cells. The mean level of serum bilirubin in patient of beta - thalassaemia major was $(1.70$ $\pm 0.70) \mathrm{mg} / \mathrm{dl}$ and the same level of bilirubin in patient of $\mathrm{Hb}$-Ebeta thalassaemia was (2.18 $\pm 0.66) \mathrm{mg} / \mathrm{dl}$. A statistically significant mean difference of serum bilirubin was found indicating beta - thalassaemia major had lower bilirubin than patient of $\mathrm{HbE}$ beta - thalassaemia in $\mathrm{p}$ value $<0.05$ level. This finding pointed that haemolysis was occurring more in our study subjects of $\mathrm{HbE}$ beta - thalassaemia than beta thalassaemia major. Peaeson's Correlation between serum bilirubin of patients in $\mathrm{mg} / \mathrm{dl}$ and serum ferritin of patients in $\mathrm{ng} / \mathrm{ml}$ had studied in two ways as a whole correlation between bilirubin of all the patients in $\mathrm{mg} / \mathrm{dl}$ and serum ferritin in $\mathrm{ng} / \mathrm{ml}$ had $\mathrm{r}$ value -.26 was statistically insignificant at $0 / 05$ level. On the 
other side correlation between serum bilirubin of the patient of beta - thalassaemia major in $\mathrm{mg} / \mathrm{dl}$ and serum ferritin of same patients in $\mathrm{ng} / \mathrm{ml}$ had $\mathrm{r}$ value -0.10 was statistically insignificant at the 0.05 level. And correlation between serum bilirubin of the patients of $\mathrm{HbE}$ beta thalassaemia in $\mathrm{mg} / \mathrm{dl}$ and serum ferritin of same patients in $\mathrm{ng} / \mathrm{ml}$ had $\mathrm{r}$ value -0.16 was statistically insignificant at the level 0.05 . this finding indicates there is no correlation at all between serum ferritin level and bilirubin in thalassaemia patients.

Iron over load and jaundice are common finding of thalassaemia. In this present study serum ferritin and serum bilirubin parameter of iron over load and jaundice are correlated. But no statistical correlation was found between these two parameters.

\section{References}

1. Weatherall DJ, Clegg JB, Thalassaemia - a global public health problem. Nat Med, 1996:2,847-9.

2. Firkin F, Chesterman C, Penington D, Rush B.(eds)1996, de Gruchy,s Clinical Hematology in Medical Practice.5th ed, Blackwell, Australia, 137.

3. Olivieri NF, Weatherall DJ. Recent progress in the Management of thalassaemia. HKJ Paediatr (New series) 1996; 1: 14-22.

4. Higgs DR, Thein SL, Woods WG. The molecular pathology of Thalassaemia. In: Weatherall DJ, Clegg B, eds. The Thalassaemia syndromes. 4th ed. Oxford, England: Blackwell science, 2001: 133-91.

5. Lehmann H, Carrell RW. Differences between alpha and beta chain mutants of human hemoglobin and between alpha and beta thalassaemia. Possible duplication of alpha chain gene. Br. Med J 1968; 4 (5633) 748 - 750.
6. Hoffbrand AV, Cohen A , Hershko C. Role of deferiprone in chelation therapy for transfusion iron overload. Blood 2003; 102: 17- 24.

7. Olivieri NF. The beta thalassaemias. N engl J Med 1999; 341: 99 - 109.

8. WHO guideline for the Hemoglobin Disorders. Unpublished document WHO/HDP/HB/GL/94. Obtained free of charge from the hereditary Disease Programme. WHO, Geneva, Switzerland.

9. Khan WA, Banu B, Amin SK et al. prevalence of beta thalassaemia trait and HB-E trait in Bangladeshi school children and health burden of thalassaemia in our population.2005; 21(1): 1-7.

10. Voskaridou E, Douskou M, Terpose E, et al. magnetic resonance imaging in the evaluation of iron overload in patients with ? - thalassaemia and sickle cell disease. $\mathrm{Br}$ J Haematol 2004; 126: 736 - 742.

11. Papanikolaou G, Tzilianos M, Christakis JI, et al. Hepcidin in iron overload disorders. Blood 2005; 105:4103 - 5.

12. Hershko C, Konijn AM, Link G. Iron chelators for thalassaemia. Br J Haematol 1998; 101: 399 - 406.

13. Olivieri NF, Brittenham Gm: Iron- chelating therapy and the treatment of thalassaemia. Blood 1997; 89: 739.

14. Nelson R, Chawla M, Connolly P, Laporte J. Ferritin as an index of bone marrow iron store. South Med J 1978; 71: 1482 - 1484.

15. Valberg LS . Plasma ferritin concentration, its clinical significance and relevance to patients care. Can Med Assoc J 1980; 122: 1240 -1248.

16. Jabobs A, Worwood M. Serum ferritin concentration in health and disease. N Eng J Med $1975 ; 292: 951$ - 2.

17. Jacobs A, Miller F, Worwood M. Ferritin in serum in normal subjects and patients with iron deficiency and iron overload. Br Med J 1972; 4206 - 208.

18. Lipschitz DA, Cook JD, Finch Ca. Aclinical evaluation of sewrum ferritin as an index of iron store. $\mathrm{N}$ Eng $\mathrm{J}$ Med1974; 290: 1213 - 1216.

19. Purnamawati SP, Pamella K, IMral C, Julfina B, Hanifah O. Profile of alanine aminotransferase and hepatic accumulation in thalassaemia patients with or without antihepatitis C virus. Paedriatica Indonesiana 2004; 44(5 6): $85-88$. 